\title{
Assessing the Knowledge Level of Beekeepers on Improved Beekeeping Management Practices in Peri-Urban Areas of Southwestern Nigeria
}

\section{Sunday I. Ogunjimi, Abiodun O. Ajala \& Chinwe Egbunonu}

To cite this article: Sunday I. Ogunjimi, Abiodun O. Ajala \& Chinwe Egbunonu (2016) Assessing the Knowledge Level of Beekeepers on Improved Beekeeping Management Practices in PeriUrban Areas of Southwestern Nigeria, Journal of Agricultural \& Food Information, 17:2-3, 162-173, DOI: $10.1080 / 10496505.2015 .1124781$

To link to this article: http://dx.doi.org/10.1080/10496505.2015.1124781

Published online: 07 Jul 2016.

Submit your article to this journal $\sqsubset$

a

View related articles $\sqsubset$

View Crossmark data ¿ 


\title{
Assessing the Knowledge Level of Beekeepers on Improved Beekeeping Management Practices in Peri-Urban Areas of Southwestern Nigeria
}

\author{
Sunday I. Ogunjimi ${ }^{a}$, Abiodun O. Ajala ${ }^{b}$, and Chinwe Egbunonu ${ }^{a}$ \\ a Department of Agricultural Economics and Extension, Federal University Oye-Ekiti, Ekiti State, Nigeria; \\ ${ }^{b}$ Department of Agricultural Economics and Extension, Landmark University Omu-Aran, Kwara State, \\ Nigeria
}

\begin{abstract}
The study was conducted to assess beekeepers' knowledge of improved management practices in peri-urban areas of southwestern Nigeria. A multistage sampling procedure was employed to select 90 respondents from the study area. Results show that beekeepers in southwestern Nigeria had inadequate knowledge of improved beekeeping management practices, which resulted in low skill in most of the practices. Most of the beekeepers encountered problems ranging from inadequate skill, drought, honeybee pests and diseases, and death of the colony. The authors recommend that farmers be well-trained in improved management practices so as to enhance food security.
\end{abstract}

\section{ARTICLE HISTORY}

Received 10 June 2015

Accepted 23 November 2015

\section{KEYTERMS}

Apiculture; beekeepers; beekeeping; bees; skill; management practices; knowledge; Nigeria

\section{Introduction}

Beekeeping (apiculture) has been an important part of agriculture in southwestern Nigeria for ages. Before the development of sugarcane refining in the 19th century, honey was the only widely available sweetening agent (Farinde, Soyebo, \& Oyedokun, 2005). Honey bees (Apis mellifera) are one of the most well-known, popular, and economically beneficial insects. The Technical Centre for Agricultural and Rural Cooperation (CTA, 2007, p. 1) identifies the following economic reasons for keeping bees: bees pollinate crops and thus help increase yields; high demand for honey exists in local, regional, and international markets; propolis, collected from plants by bees to cover the inside of the hive, treats a broad range of ailments; pollen collected from plants by bees to feed their larvae, is used in the perfume industry, and is a food additive and a medicine; royal jelly, made by young bees from gland secretions and fed to the queen to make her strong, has medicinal properties; and beewax is used in cosmetics, candles, and polishes.

CONTACT Sunday I.Ogunjimi @imisunday@yahoo.co.uk or jimisunday@gmail.com @ Department of Agricultural Economics and Extension, Federal University Oye-Ekiti, Ekiti State, Nigeria. 
Honeybees can be kept almost anywhere where there are flowering plants that produce nectar and pollen. While indigenous beekeepers kept bees in primitive hives or cut down bee trees to get honey for home use and for sale (Jaycox, 1985), modern-day beekeeping utilizes improved management practices and equipment which includes the bee hive, which is made up of a bottom board (wooden stand on which the hive rests), frames and foundation (wooden frames that hold sheets of beeswax), hive body (a large wooden box holding the frames), and an excluder placed between the brood nest and the honey supers (shallow boxes, with frames of comb in which bees store surplus honey). This surplus is the honey that is harvested by the beekeeper.

Seasonal beekeeping management practices include retrieving swarms, transferring bees, and honey harvesting. An on-going (weekly or monthly) management practice in honey production is the regular inspection of the colony once it is established. Farinde et al. (2005, p. 33) indicate this inspection is to assess the status of the brood, space needs for expansion and reduction of the population for nectar flow during build-up and dearth periods, and adequacy of honey stores and to detect possible invasion of the colony by predators.

In Nigeria, most honeybees are reared in hives constructed of wooden reeds and tree trunks. Harvesting is carried out with crude technologies. This has limited the quantity and quality of honey produced in southwestern Nigeria (Oluwatusin, 2006). The low yield of honey and other beekeeping products results from insufficient management practices and lack of adequate beekeeping training (Bhusal \& Thapa, 2005; Masuku, 2013). In an effort to increase honey production and quality and other allied products, the Nigerian government extension service, working through the Agricultural Development Programme (ADP), has encouraged beekeepers in southwestern. Nigeria to adopt improved management practices. This initiative has resulted insignificant improvement in the management of hives, bees, and production of honey and wax. Therefore, this study was conducted to assess beekeepers' level of knowledge of improved beekeeping management practices in peri-urban areas of southwestern Nigeria. The specific objectives were to:

1. examine beekeepers' socioeconomic characteristics in the study area;

2. assess the level of awareness of improved management practices introduced to beekeepers;

3. determine farmers' level of knowledge of improved management practices;

4. assess the skill level of beekeepers in improved management practices; and

5. identify the constraints to beekeeping and honey production in the study area.

\section{Methodology}

The study was carried out in Osun and Ekiti States of southwestern Nigeria between the months of March and April 2015, because of these states' known high potential for honey production. The interview schedule was administered five years after the introduction of improved management practices to beekeepers by the Agricultural 
Development Project of Nigeria, under the National Fadama Development Project supported by the World Bank intervention between 2008 and 2013.

The target group for the study consisted of the members of the Beekeepers' Association of Nigeria (BAN). A multistage sampling procedure was employed to select the respondents from the study area. At the first stage, three major beekeeping and honey-producing Local Government Areas (LGAs) were selected. In the second stage, three communities were selected from each LGA. In the last stage, 10 beekeepers were randomly selected from each community giving a total of 90 respondents.

Farmers' knowledge of honey production was determined using respondents' mean test scores on survey questions related to knowledge of swarming, hiving, baiting, identification of nectar and honey flow periods, determination of ripe honey, time of harvest, correct method of honey extraction from the comb, and record keeping. The scoring of each practice was done on a 4-point Likert scale with "highly knowledgeable" scored as 3, "moderately knowledgeable" scored as 2, "low knowledge" scored as 1, and "not knowledgeable" scored as 0 (Vogt, 1999). The mean score with standard deviation was used to categorize the knowledge level into high, moderate, and low levels. A score of mean plus standard deviation was considered as "high" knowledge level, mean minus standard deviation was considered as "low," and the difference between high and low was considered as "moderate" knowledge level. Awareness was determined through scoring each practice on a three-point Likert scale with "have seen" scored as 3, "have heard" as 2, and "never heard" as 1 . Skill was determined through scoring each practice on four-point Likert scale with "high skilled" scored 3, "moderately skilled "scored 2, "low skilled "scored 1, and "no skill" scored 0. The data were processed using the SPSS package Version 16 (SPSS Inc., Chicago, IL, USA) and descriptive statistics such as mean, percentage, frequencies, and regression analysis were used to analyze the data.

\section{Results and discussion}

The socioeconomic characteristics of respondents, presented in Table 1, show that $51.1 \%$ were between the ages of 30 and 60 years. This indicates that the majority of the beekeepers in southwestern Nigeria were within a productive age range. Furthermore, the majority (63.3\%) were males. These demographics corroborate the findings of Tijani, Ala, Maikasuwa, and Ganawa (2011) who reported that the majority (90\%) of the beekeepers in Nigeria are male and opined that this might be the result of male farmers' greater responsibility for the feeding of household members. Thus, they may engage more in beekeeping to supply their households with food and other basic needs. Analysis further shows that the majority (87.8\%) of beekeepers realized annual income of less than 51,000 Naira per annum (US\$252.52), which is less than the World Bank standard of US\$1 per day (US\$365 per annum) for people in developing countries. This is an indication that the majority of the respondents generated low income from the sale of honey, which might be as a result of small-scale and crude methods of honey production. If farmers expand their scope of production, income would likely increase. 
Table 1. Distribution of beekeepers according to socioeconomic characteristics.

\begin{tabular}{|c|c|c|c|}
\hline Variables & Frequency & Percentage & Mean/Standard Deviation \\
\hline \multicolumn{4}{|l|}{ Age } \\
\hline$<30$ & 13 & 14.4 & \\
\hline $30-60$ & 46 & 51.1 & \\
\hline$\geq 61$ & 31 & 34.5 & $42.5 / 13.8$ \\
\hline \multicolumn{4}{|l|}{ Sex } \\
\hline Male & 57 & 63.3 & \\
\hline Female & 33 & 36.7 & \\
\hline \multicolumn{4}{|l|}{ Marital status } \\
\hline Single & 58 & 64.4 & \\
\hline Married & 26 & 28.9 & \\
\hline Divorced & 6 & 6.7 & \\
\hline \multicolumn{4}{|l|}{ Level of education } \\
\hline Never & 1 & 1.1 & \\
\hline Primary school & 18 & 20.0 & \\
\hline Secondary school & 46 & 51.1 & \\
\hline Tertiary & 25 & 27.8 & \\
\hline \multicolumn{4}{|l|}{ Type of occupation } \\
\hline Full-time occupation & 5 & 5.6 & \\
\hline Part-time occupation & 85 & 94.4 & \\
\hline \multicolumn{4}{|c|}{ Extension contact in the last 1 year } \\
\hline No contact & 27 & 30.0 & \\
\hline $1-4$ & 44 & 48.9 & $3.8 / 1.2$ \\
\hline 5 and above & 19 & 21.1 & \\
\hline \multicolumn{4}{|c|}{ Training attended in the last 1 year } \\
\hline Never attend training & 46 & 51.1 & \\
\hline $1-4$ & 35 & 38.9 & $3.6 / 0.9$ \\
\hline 5 and above & 9 & 10.0 & \\
\hline \multicolumn{4}{|l|}{ Source of training* } \\
\hline Extension agents & 40 & 44.4 & \\
\hline Research institutes & 27 & 30.0 & \\
\hline Cooperative society & 13 & 14.4 & \\
\hline NGO & 10 & 11.1 & \\
\hline Contact farmers & 10 & 11.1 & \\
\hline \multicolumn{4}{|l|}{ Source of information* } \\
\hline Other farmers & 64 & 71.1 & \\
\hline Extension agents & 42 & 46.7 & \\
\hline Cooperative society & 35 & 38.9 & \\
\hline Research institutes & 38 & 42.2 & \\
\hline Mass media & 40 & 44.4 & \\
\hline NGO & 22 & 24.4 & \\
\hline \multicolumn{4}{|c|}{ Income realized from beekeeping/annum (Naira) } \\
\hline$\leq 10,000$ & 9 & 10.0 & \\
\hline $11,000-20,000$ & 29 & 32.2 & \\
\hline $21,000-30,000$ & 12 & 13.3 & $29,435 / 7,065$ \\
\hline $31,000-40,000$ & 12 & 13.3 & \\
\hline $41,000-50,000$ & 17 & 18.9 & \\
\hline 51,000 and above & 11 & 12.2 & \\
\hline
\end{tabular}

Note. Source: Field survey, 2015.

*Multiple responses.

The educational attainment of beekeepers plays an important role in their ability to acquire new techniques and technologies. The majority of the beekeepers surveyed (98.9\%) were literate, while only one of the beekeepers had never been to school. This indicates that most farmers can read instructional manuals. High educational levels imply that beekeepers could be easily trained in improved management practices. Ayansola (2012), in a study of apicultural practices in southwestern Nigeria, reported that a majority of the respondents (76.1\%) had between 11 and 20 years of formal education. Also, Mujuni, Natukunda, and Kugonza (2012) 
found thatbeekeepers surveyed in western Uganda had attained secondary or tertiary education. The similar findings with respect to education show that beekeeping is undertaken by the educated, which may stimulate acceptance of improved technologies, since education facilitates farmers' adoption of innovations (Natukunda, Kugonza, \& Kyarisiima, 2011; Onemolease, 2005).

Almost all of the respondents (94.4\%) engaged in beekeeping as a part-time business, while the other $5.6 \%$ did it full-time. This indicates that many people have not realized the full economic potential of beekeeping as a source of income and employment generation. This finding is consistent with that of Ayansola (2012), who reported that a majority of beekeepers keep bees part-time.

Almost half (48.9\%) of the respondents indicated they had between one and four contacts with extension agents in a year. This is abysmally low in a country where the Training and Visit (T\&V) system is practiced, where extension agents are expected to visit contact farmers at least twice a month (24 times per annum; Akubuilo, 2008). The low contact is obviously the result of the low national average extension agent to farmer ratio of 1:1986 in Nigeria (Ihimodu, 2002).

\section{Beekeepers' awareness of improved management practices}

Table 2 shows that the grand mean awareness score of the respondents for improved management practices in beekeeping was 2.0. Mean scores were calculated and ranked in descending order of awareness. Processing practices, such as use of correct method of honey extraction from the comb were ranked first $(M=2.9)$, followed by marketing of honey and beeswax $(M=2.8)$; packaging $(M=2.7)$; site selection $(M=2.7)$; hive installation $(M=2.5)$; routine inspection $(M=2.5)$; prevention of swarming $(M=2.3)$; time of harvesting $(M=2.3)$; identification of nectar ( $\mathrm{M}=2.1)$; baiting $(\mathrm{M}=2.1)$; determination of ripe honey $(M=2.1)$; and robbing, disease and pest control $(M=2.0)$. Feeding $(M=1.9)$ and recordkeeping $(M=$ 1.5) were ranked lowest. Figure 1 shows that $64.4 \%$ had high level of awareness

Table 2. Beekeepers' awareness of improved management practices in mean rank order.

\begin{tabular}{lcc}
\hline Improved Management Practices & Mean & Rank \\
\hline Processing such as use of right method of honey extraction from the comb & 2.9 & 1 st \\
Marketing of honey and beeswax & 2.8 & 2 nd \\
Packaging & 2.7 & 3 rd \\
Site selection & 2.7 & 3 rd \\
Hive installation & 2.5 & 5 th \\
Routine inspection & 2.5 & 5 th \\
Prevention of swarming & 2.3 & 7 th \\
Time of harvesting & 2.3 & 7 th \\
Identification of nectar & 2.1 & 9 th \\
Determination of ripe honey & 2.1 & 9 th \\
Baiting & 2.1 & 9 th \\
Robbing, disease and pest control & 2.0 & 12 th \\
Feeding & 1.9 & 13 th \\
Recordkeeping & 1.5 & 14 th \\
Grand mean & 2.0 & \\
\hline
\end{tabular}

Note. Source: Field survey, 2015. 


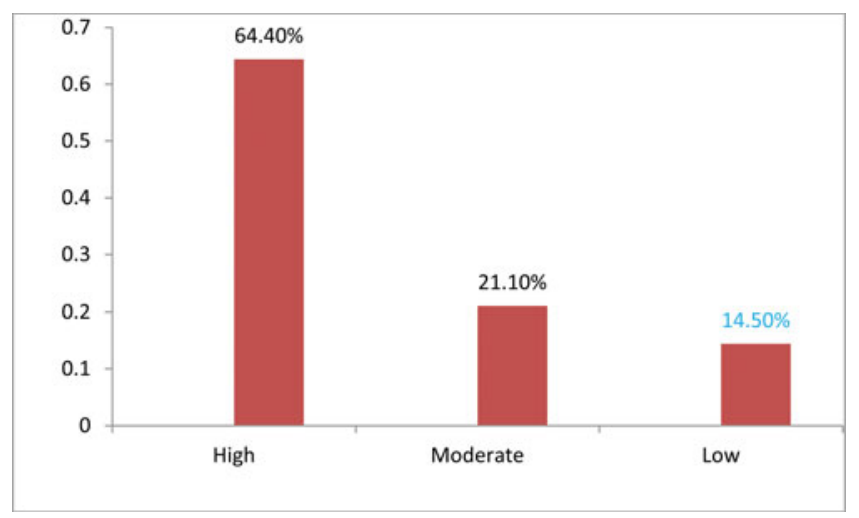

Figure 1. Beekeepers' Level of Awareness of Improved Management Practices.

of all the management practices, $21.1 \%$ had moderate, and $14.5 \%$ had low awareness. The findings indicate that beekeepers were highly aware of the improved management practices except feeding and recordkeeping, of which they have low awareness.

\section{Beekeepers' knowledge of management practices}

Table 3 shows that the grand mean score for the beekeepers knowledge of management practices was 1.51. The rank order of knowledge levels in beekeeping management practices is as follows: marketing of honey and beeswax $(M=1.98)$; processing practices, such as use of correct method of honey extraction from the comb $(M=1.85)$; storage $(M=1.68)$; packaging $(M=1.57)$; hive installation $(M=1.55)$; baiting $(M=1.53)$; knowledge of swarming $(M=1.36)$; routine inspection $(M=$ 1.35); robbing, disease and pest control $(M=1.35)$; identification of nectar and honey flow periods $(M=1.33)$; determination of ripe honey $(M=1.31)$; time of harvest $(M=1.30)$; feeding $(M=1.25)$; and recordkeeping $(M=1.24)$. It could

Table 3. Beekeepers' knowledge of improved management practices in mean rank order.

\begin{tabular}{lcc}
\hline Management Practices & Mean & Rank \\
\hline Marketing of honey and beeswax & 1.98 & $1 \mathrm{st}$ \\
Processing such as use of right method of honey extraction from the comb & 1.85 & 2 nd \\
Storage & 1.68 & 3 rd \\
Packaging & 1.57 & 4 th \\
Hive installation & 1.55 & 5 th \\
Baiting & 1.53 & 6 th \\
Knowledge of swarming & 1.36 & 7 th \\
Routine Inspection & 1.35 & 8 th \\
Robbing, disease and pest control & 1.35 & 8 th \\
Identification of nectar & 1.33 & 10 th \\
Determination of ripe honey & 1.31 & 11 th \\
Time of harvest & 1.30 & 12 th \\
Feeding & 1.25 & 13 th \\
Recordkeeping & 1.24 & 14 th \\
Grand mean & 1.51 & \\
\hline
\end{tabular}

Note. Source: Field survey, 2015. 


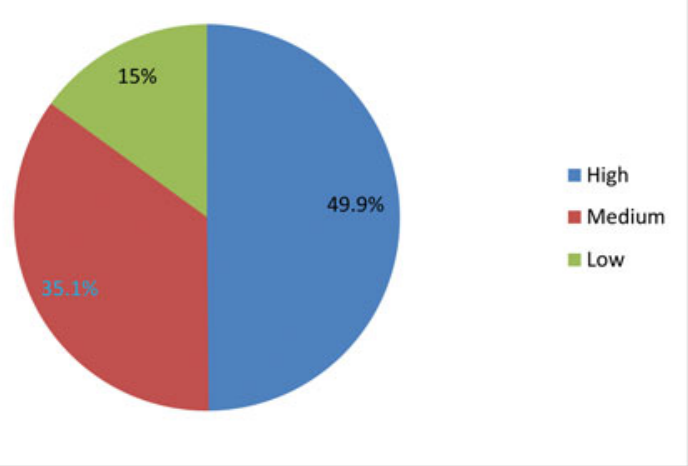

Figure 2. Pie Chart Showing the Knowledge Level of Beekeepers on Improved Management Practices.

be inferred from the findings that the majority of the beekeepers had low knowledge of the management practices, except for marketing, processing, and storage, in which they were moderately knowledgeable. The moderate knowledge of marketing, processing, and storage might be due to the beekeepers' indigenous experience in bush honey harvesting in which fire is used to drive away the bees in order to harvest honey for processing and sale in the local market. This practice can lead to bee death. Such wild honey hunters do not rear bees and may not have the technical know-how (management practices) with regard to beekeeping.

Figure 2 depicts the beekeepers' level of knowledge in improved management practices. Almost half (49.9\%) were moderately knowledgeable, while $35.1 \%$ had low knowledge; only 15\% had high knowledge, despite high awareness. The higher the knowledge level, the greater the skill and higher the productivity of the beekeepers. Low and moderate knowledge levels will have a negative impact on the adoption of improved management practices and will, in turn, lead to low production of honey and other allied products. A good knowledge of accessible markets (especially in urban centers), packaging, and presentation will allow the producer to charge more for the honey produced (Paterson, 2006). Our findings are contrary to those of Farinde et al. (2005) who reported that the majority of beekeepers in Oyo State had a high level of knowledge in honey production.

\section{Skill in improved beekeeping management practices}

Skill in beekeeping management practices was calculated and ranked by mean score (see Table 4). Processing of honey was ranked first, with a mean score of 1.81 , while packaging of honey and other allied products $(M=1.57)$ ranked second. Other management practices were ranked as follows: marketing $(M=1.55)$; storage of honey and wax $(M=1.52)$; retrieving swarms through baiting of hive $(M=1.52)$; site selection $(M=1.50)$; time of harvest $(M=1.49)$; hive installation $(M=1.45)$; routine inspection $(M=1.43)$; knowledge of swarming $(M=1.42)$; determination of ripe honey $(M=1.42)$; identification of nectar $(M=1.31)$ and robbing, disease and pest control $(M=1.20)$. Record keeping $(M=1.18)$ was ranked last. The latter 
Table 4. Respondents' skill in beekeeping in mean rank order.

\begin{tabular}{lcc}
\hline Improved Management Practices & Mean & Rank \\
\hline Processing of honey & 1.81 & 1st \\
Packaging of honey and other allied products & 1.57 & 2 nd \\
Marketing & 1.55 & 3 rd \\
Storage of honey and wax & 1.52 & 4 th \\
Retrieving swarms through baiting of hive & 1.52 & 5 th \\
Site selection & 1.50 & 6 th \\
Time of harvesting & 1.49 & 7 th \\
Hive installation & 1.45 & 8th \\
Routine inspection & 1.43 & 9 th \\
Knowledge of swarming & 1.42 & 10 th \\
Determination of ripe honey & 1.42 & 10 th \\
Identification of nectar & 1.31 & 12 th \\
Robbing, disease and pest control & 1.20 & 13 th \\
Record keeping & 1.18 & 14 th \\
Grand mean & 1.50 & \\
\hline
\end{tabular}

Note. Source: Field survey, 2015

Table 5. Level of beekeepers' skill in improved management practices.

\begin{tabular}{lcc}
\hline Level of Skill & Frequency & Percentage \\
\hline Low & 50 & 55.6 \\
Medium & 31 & 34.4 \\
High & 9 & 10.0 \\
Total & 90 & 100 \\
\hline
\end{tabular}

Note. Source: Field survey, 2015.

result is consistent with a study by Mujuni et al. (2012) that reported a generally low level of record keeping in the Bushenyi District of Uganda, where beekeepers were not conversant with the importance of records on their farms, despite their high level of literacy.

With regard to the overall level of skill of beekeepers (Table 5), 55.6\% had low skill in all the improved management practices, while $34.4 \%$ were moderately skilled and only $10.0 \%$ had high skill. These results imply that the majority of the beekeepers had low skill in most of the management practices, except for in a few cases like processing, in which they claimed to be more skilled. These findings are in line with our findings on knowledge level. Since beekeepers had inadequate knowledge in almost all beekeeping management practices, it is expected that they will not be adequately skilled in those practices.

\section{Constraints to beekeeping production}

Table 6 shows the ranked mean scores of problems confronting beekeepers, in descending order of severity. Inadequate training on improved management practices (technology know-how), with a mean of 3.62, was ranked highest. This was followed by inadequate credit facilities $(M=3.59)$ and inadequate beekeeping materials $(M=3.54)$. Bee aggressiveness $(M=3.26)$ was ranked fourth. Next in the order was inadequate information on production $(M=3.18)$, followed by inadequate extension support $(M=3.12)$, shortage of bee forage $(M=2.78)$, inadequate 
processing technology $(M=2.66)$, and reduction of honeybee colonies $(M=2.50)$. Unavailability of market $(M=2.23)$ was ranked 10 th and inadequate storage facilities last $(M=2.11)$. The findings indicate that the first nine problems encountered by the beekeepers were considered major problems, with an above average mean score of 2.50. It could be interpreted that most of the beekeepers surveyed encountered a lot of problems. This supports the finding by Ouma, De Groot, and Owour (2006) that access to credit is prominent among the problems affecting farmers' use of improved agricultural technologies. Our findings are also in line with those of Fakayode, Babatunde, Olowogbon, and Adesuyi (2010), who reported that beekeepers in Ekiti State were faced with many of the same problems such as inadequate credit, pests and diseases, bee aggressiveness, bush burning, absconding of bees, theft, inadequate technical assistance, and poor markets. Farmers who have access to training and credit are more likely to adopt improved technologies than farmers who do not have access to training and credit facilities. This is because adoption of improved technologies may require extra resources and commitment that can only be met through acquisition of knowledge and other material incentives.

Poor market accessibility is also one of the major problems faced by beekeepers in other developing countries. According to a study carried out by Yirga and Teferi (2010) in Ethiopia, the market for honey is generally poor, mainly due to a limited number of buyers, poor market infrastructure, and poor market information. Ethiopian beekeepers in the Tigray region also cited other critical constraints and problems affecting honey production-including inadequate availability of production technologies; limited availability of bee flora, mainly due to deforestation; and lack of beekeeping knowledge and skill.

\section{Hypotheses testing}

Table 7 presents the results of the regression analysis on selected personal and socioeconomic characteristics of beekeepers. Regression analysis was used in order to show the magnitude of change in the knowledge level of beekeepers as a result of a unit change in the selected independent variables. The results of regression coefficient $(b)$ show that years of schooling $(b=.173 ; p \leq .01)$ result in a high

Table 6. Constraints to beekeeping in mean rank order.

\begin{tabular}{lcc}
\hline Constraints & Mean & Rank \\
\hline Inadequate training on improved management practices & 3.62 & 1 st \\
Inadequate credit facilities & 3.59 & 2 nd \\
Inadequate beekeeping materials & 3.54 & 3 rd \\
Bee aggressiveness & 3.26 & 4 th \\
Inadequate information on production & 3.18 & 5 th \\
Inadequate extension support & 3.12 & 6 th \\
Shortage of bee forage & 2.78 & 7 th \\
Inadequate processing technology & 2.66 & 8 th \\
Reduction of honeybee colonies & 2.50 & 9 th \\
Unavailability of market & 2.23 & 10 th \\
Inadequate storage facilities & 2.11 & 11 th \\
\hline
\end{tabular}

Note. Source: Field survey, 2015. 
magnitude of change in beekeepers' knowledge of improved management practices, which implies that a unit increase in years of schooling would result in an increase in beekeepers' level of knowledge. This may be because, the more the farmers seek knowledge, the more likely they develop interest in the improved practices and the higher their level of involvement. Results of regression coefficient (b) further show that income realized and extension contact $(b=.177 ; p \leq 0.05)$ correlate significantly with beekeepers' level of knowledge of improved management practices. The implication of this is that a unit increase in extension contact would result in an increase in the level of knowledge of improved beekeeping management practices. The reason for this increase might be because an increase in extension agent contact would increase information flow to beekeepers, which would lead to increased knowledge of improved management practices and, in turn, increase their skill. A unit increase in income realized from sales of honey and other allied products will also bring about an increase in the level of usage of improved management practices and level of knowledge. This implies that an increase in the income realized by beekeepers from sales of honey and other allied products will serve as an incentive to become more involved in management practices, which will increase their level of knowledge.

\section{Conclusion and recommendations}

Beekeepers in southwestern Nigeria have inadequate knowledge of improved management practices in beekeeping, resulting in low skill in most practices. The major problems confronting peri-urban beekeepers include inadequate knowledge of improved management practices, lack of credit facilities, untimely supply of inputs, inadequate information, low extension contact, and inadequate processing technology. The results of regression analysis show that a unit increases in years of schooling, extension contact, and income are correlated with an increase in the level of knowledge of improved management practices. It is recommended that adequate training on improved beekeeping management practices be organized by the Nigerian government through the extension agencies and non-governmental organizations. Moreover, there should be follow-up visits by extension agents to ensure that the desired results in beekeepers' knowledge and skills are achieved. Nigerian agricultural engineers should be empowered to combine beekeepers' indigenous

Table 7. Multiple regression analysis showing the relationships between respondents' personal, socioeconomic characteristics, and knowledge level.

\begin{tabular}{lccc}
\hline Variables & Regression Coefficient (b) & $t$-Value & $p$-Value \\
\hline Age (year) & -.044 & 0.555 & .579 \\
Extension contact & $.177^{*}$ & -1.468 & .043 \\
Years of schooling & $.173^{* *}$ & 3.090 & .002 \\
Income realized by beekeepers & $.037^{* *}$ & 7.477 & .000 \\
Constant & 12.443 & 1.956 & .510 \\
\hline
\end{tabular}

Note. Source: Field survey, 2015.

*** Significant at $p \leq .01$.

*Significant at $p \leq .05$. 
knowledge with modern knowledge to devise appropriate adaptive technology. If these recommendations are put in place, an increase in honey production may be achieved.

\section{References}

Akubuilo, C. J. C. (2008). History of agricultural extension in Nigeria. In O. A. Akinyemiju \& D. O. Torimiro (Eds.), Agricultural extension: A comprehensive treatise (pp. 1-8). Lagos, Nigeria: ABC Agricultural Systems.

Ayansola, A. A. (2012). An appraisal of apicultural practices in southwestern Nigeria. Journal of Agricultural Science, 3(2), 79-84.

Bhusal, S. J., \& Thapa, R. B. (2005). Comparative study on the adoption of improved beekeeping technology for poverty alleviation. Journal of the Institute of Agriculture and Animal Science, $26,117-125$.

Fakayode, S. B., Babatunde, R. O., Olowogbon, S. T., \& Adesuyi, W. S. (2010, September). An appraisal of beekeeping activities among beneficiaries and non-beneficiaries of Ekiti State Agricultural Credit Agency (ESACA) Scheme in Nigeria. Retrieved from http://purl. umn.edu/95785

Farinde, A. J., Soyebo, K. O., \& Oyedokun, M. O. (2005). Improving farmers' attitude towards natural resources management in a democratic and deregulated economy: Honey production experience in Oyo State of Nigeria. Journal of Human Ecology, 18(1), 31-37.

Ihimodu, I. I. (2002). Strategy for poverty alleviation among small-scale farm holders through participatory research and extension. Paper presented at the 14th Middle Belt Zonal ResearchExtension Farmer-Input Linkage System (REFILS) Workshop, Ilorin, Nigeria.

Jaycox, E. R. (1985). Beekeeping in the Midwest (Circular 1125, University of Illinois Cooperative Extension Service). Retrieved from http://www.ag.uiuc.edu/ vista/html_ pubs/BEEKEEP/forward.html

Masuku, M. B. (2013). Socioeconomic analysis of beekeeping in Swaziland: A case study of the Manzini Region, Swaziland. Journal of Development and Agricultural Economics, 5(6), 236241.

Mujuni, A., Natukunda, K., \& Kugonza, D. R. (2012). Factors affecting the adoption of beekeeping and associated technologies in Bushenyi District, western Uganda. Livestock Research for Rural Development, 24(8), Article \#133. Retrieved from http://www.lrrd.org/ lrrd24/8/muju24133.htm

Natukunda, K., Kugonza, D. R., \& Kyarisiima, C. C. (2011). Indigenous chickens of the Kamuli Plains in Uganda: II. Factors affecting their marketing and profitability. Livestock Research for Rural Development, 23(10), Article \#221. Retrieved from http://www.lrrd.org/ $\operatorname{lrd} 23 / 10 /$ natu23221.htm

Oluwatusin, F. M.(2006). Costs and returns in modern beekeeping and honey production in Nigeria. Medwell Pakistan Journal of Social Science, 5(4), 310-315.

Onemolease, E. A. (2005). Impact of the Agricultural Development Programme (ADP) activities in arable crop production on rural poverty alleviation in Edo State, Nigeria (Doctoral thesis). University of Benin, Benin City, Edo State, Nigeria.

Ouma, J. O., De Groot, H., \& Owour, O. (2006, August). Determinants of improved maize seed and fertilizer use in Kenya: Policy implications. Paper presented at the International Association of Agricultural Economists' Conference, Gold Coast, Australia.

Paterson, P. D. (2006). Beekeeping. Oxford, UK: Macmillan.

Technical Centre for Agricultural and Rural Cooperation. (2007). How to keep bees and process honey (CTA Practical Guide Series, No. 13). Wageningen, The Netherlands: 
ACP-EU Technical Centre for Agricultural and Rural Cooperation (CTA). Retrieved from http://www.anancy.net/documents/file_en/013_Beekeeping_v0300A4.pdf

Tijani, B. A., Ala, A. L., Maikasuwa, M. A., \& Ganawa, N. (2011). Economic analysis of beekeeping in Chibok Local Government Area of Borno State, Nigeria. Nigerian Journal of Basic and Applied Science, 19(2), 285-292. Retrieved from http://www.ajol.info/ index.php/njbas/article/download/73900/64577

Vogt, W. P. (1999). Dictionary of statistics and methodology. Thousand Oaks, CA: Sage.

Yirga, G., \& Teferi, M. (2010). Participatory technology and constraints assessment to improve the livelihood of beekeepers in Tigray Region, northern Ethiopia. Momona Ethiopian Journal of Science, 2(1), 76-92. Retrieved from http://dx.doi.org/10.4314/mejs.v2i1.49654 